\title{
PENGEMBANGAN LKS BERBASIS PENDEKATAN REALISTIC MATHEMATICS EDUCATION UNTUK MENINGKATKAN KEMAMPUAN MATEMATIS SISWA
}

\author{
Tri Andari ${ }^{1)}$, Eva Komsiatun ${ }^{2)}$ \\ 1), 2) Universitas PGRI Madiun. \\ E-mail:trianmath03@gmail.com ${ }^{1)}$ \\ evakomsiatun@gmail.com ${ }^{2)}$
}

\begin{abstract}
This research aims to develop worksheets students (worksheets) based on this Mathematics Education (RME) to improve the matematical ability of elementary school student. The subject of this research is the students of class $V$ Elementary School of Muneng and students in grade 5 Elementary School of Pulerejo 3. The type of this research is the Research and Development, with development model Four-D (4D), which is divided into 4 stages, namely: stage defining (define), stage design(design), development stage $(\cdot$ develop), spreading stage (disseminate). This research done only until the development phase (develop). The products of this research is a Worksheet Students (worksheets) based on this Mathematics Education (RME) a syllabus, denunciating, worksheets, and THB through Fax Banking. The results of the study showed that the average validity is $82,689 \%$ stated valid, the results of the average convenience of a limited test is $88,75 \%$ and field tests is $80.7 \%$ stated practical, and the results of the average effectiveness of limited test is $89,33 \%$ and field tests $86 \%$ is declared effective. Based on the results of research that the students work sheet (worksheets) based on this Mathematics Education (RME) on the matter arose space stated valid, practical, and effective and improve the matematical ability of elementary school student so that it can be used in the mathematics teaching.
\end{abstract}

Keywords: Matematics, Realistic Mathematics Education, student's worksheet.

\section{PENDAHULUAN}

Pendidikan adalah usaha sadar dan terencana untuk mewujudkan suasana belajar dan proses pembelajaran agar siswa secara aktif mengembangkan potensi dirinya untuk memiliki kekuatan spiritual keagamaan, pengendalian diri, kepribadian, kecerdasan, akhlak mulia, serta keterampilan yang diperlukan dirinya, masyarakat, bangsa dan negara. Pendidikan yang terstruktur dan berjenjang yang terdiri atas pendidikan dasar, pendidikan menengah, dan pendidikan tinggi. Pendidikan diselenggarakan sebagai suatu proses pembudayaan dan pemberdayaan peserta didik yang berlangsung sepanjang hayat. Undang-Undang Sistem Pendidikan Nasional Nomor 20 Tahun 2003 pasal 11 ayat 1 : "Pemerintah dan pemerintah daerah wajib memberikan layanan dan kemudahan, serta menjamin terselenggaranya pendidikan yang bermutu bagi setiap warga negara tanpa diskriminasi". Salah satu mata pelajaran yang selalu ada di semua jenjang pendidikan adalah matematika.

Matematika merupakan bagian dari ilmu pengetahuan yang bersifat pasti (eksak), merupakan dasar ilmu yang lain. Matematika kadang dianggap sulit karena siswa kurang nyaman dengan pembelajaran yang diterapkan oleh guru di dalam kelas. Pembelajaran matematika adalah suatu aktivitas mental untuk memahami arti dan hubunganhubungan serta simbol-simbol kemudian diterapkan pada situasi nyata (Fitri, R., Helma, \& Syarifuddin, H. 2014: 18). Sedangkan cara mengajar guru terkadang membuat siswa menjadi sulit dan bingung mempelajari matematika. Materi pelajaran matematika kelas $\mathrm{V}$ di SD Negeri Muneng salah satunya 
bangun ruang. Bangun ruang yang diajarkan yaitu balok, kubus, prisma, limas, tabung, dan kerucut.

Berdasarkan observasi yang dilakukan ditemukan fakta bahwa berdasarkan ulangan harian pada materi bangun ruang, sebagian besar siswa masih memiliki nilai di bawah Kriteria Ketuntasan Minimal (KKM). Penyebabnya sumber belajar yang digunakan masih terbatas, yaitu buku paket. Berbagai sumber dapat digunakan untuk menunjang materi pembelajaran dari setiap standar kompetensi dan kompetensi dasar salah satu diantaranya adalah Lembar Kerja Siswa (LKS).

LKS merupakan lembaranlembaran berisi tugas yang harus dikerjakan oleh siswa. Kegiatan biasanya berupa petunjuk atau langkah-langkah untuk menyelesaikan suatu tugas. LKS menjelaskan materi lebih rinci serta mudah dipahami peserta didik, tugastugas terstruktur, mudah dibawa dan ringan. LKS memiliki beberapa fungsi yaitu: (1) Sebagai bahan ajar yang bisa meminimalkan peran pendidik, namun lebih mengaktifkan siswa. (2) Sebagai bahan ajar yang mempermudah siswa untuk memahami materi yang diberikan. (3) Sebagai bahan ajar yang ringkas dan kaya tugas untuk berlatih.

Memudahkan pelaksanaan pengajaran kepada siswa (Prastowo A, 2015: 205).

Kehidupan sehari-hari tidak lepas dari matematika, baik itu menghitung, bentuk bangun datar maupun bangun ruang, jual beli dan masih banyak lagi. Agar siswa paham tentang bangun ruang sebaiknya diberikan contoh di sekitarnya, salah satu contohnya meja, kaleng roti, dadu, topi ulang tahun, botol air mineral dan lain sebagainya. Berbagai contoh yang diberikan berdasarkan kehidupan sehari-hari akan membuat siswa paham dan mengerti sifat, bentuk, rumus yang dimiliki bangun tersebut. Untuk memperjelas dan memahami belajar matematika berdasarkan kehidupan sehari-hari dalam pembelajaran dapat digunakan pendekatan Realistic Mathematics Education (RME).

RME adalah suatu pendekatan pembelajaran matematika yang harus selalu menggunakan masalah sehari-hari (Wijaya A, 2012: 21-23). Salah satunya memberikan contoh dalam kehidupan sehari-hari agar siswa lebih mudah memahami konsep dan maksud dari pembelajaran. RME memiliki beberapa karakteristik diantaranya: (a) penggunaan konteks, (b) penggunaan model untuk matematisasi progresif, (c) pemanfaatan hasil konstruksi, (d) interaktivitas, (e) keterkaitan.

LKS dapat dipadupadankan dengam pendekatan Realistic Mathematics Education (RME) yaitu LKS yang berbasis Pendekatan Realistic Mathematics Education (RME). Selain bahan ajar yang berkualitas, pendekatan Realistic Mathematics Education (RME) memberikan solusi dalam menciptakan pembelajaran yang mudah dipahami. Sehingga tercapainya tujuan pembelajaran yang diinginkan, yaitu pemahaman materi bangun ruang kelas V.

Berdasarkan uraian diatas,
penelitian ini bertujuan untuk
menghasilkan LKS berbasis pendekatan
Realistic Mathematics Education (RME)
yang valid, praktis, dan efektif serta
untuk meningkatkan kemampuan
matematis siswa.

\section{METODE PENELITIAN}

Penelitian ini dilakukan di kelas V SD Negeri Muneng dan SD Negeri Pulerejo 3 Tahun Ajaran 2016/2017 yang menerapkan kurikulum KTSP. Instrumen pengumpul data pada penelitian ini terdiri atas instrumen soal dan angket. Instrumen soal yang dibuat adalah instrumen soal yang berpedoman 
pada skala standar RME dan di sesuaikan dengan kurikulum KTSP. Angket yang digunakan dalam penelitian ini adalah angket respon siswa.

Penelitian yang digunakan adalah Research and Development $(R \& D)$ yang sering disebut penelitian pengembangan dengan tujuan untuk mengembangkan LKS berbasis pendekatan Realistic Mathematics Education (RME). Hal ini sesuai dengan pendapat Sugiyono (2015) yang menyatakan bahwa metode penelitian dan pengembangan dapat diartikan sebagai cara ilmiah untuk meneliti, merancang, memproduksi dan menguji validitas produk yang telah dihasilkan. Penelitian ini menggunakan model 4-D yang terdiri dari 4 tahap pengembangan yaitu pendefinisian (Define), perancangan (Design), pengembangan (Develop), dan penyebaran (Disseminate).

Pengembangan LKS berbasis pendekatan Realistic Mathematics Education (RME) ini meliputi kegiatan pembuatan prototype LKS berbasis pendekatan Realistic Mathematics Education (RME) menggunakan Microsoft Office Word 2007, pembuatan instrumen soal, validator (ahli dan praktisi), revisi, uji coba, dan revisi akhir. Validator yang terdiri dari dua orang yaitu orang yang memiliki kompetensi di bidang matematika dan media. Hal tersebut dilakukan untuk memperoleh validitas LKS berbasis pendekatan Realistic Mathematics Education (RME) dan instrumen soal diujicobakan. Uji coba dilakukan pada siswa kelas V SD di Kabupaten Madiun. Uji coba dilakukan dalam dua tahap yaitu : 1) Uji coba kelompok kecil; uji coba kecil termasuk validasi empirik produk. Uji coba ini dilakukan kepada 6 orang siswa kelas V SD Negeri Pulerejo 3 yang memiliki kemampuan bervariasi (tinggi, sedang, dan rendah). 2) uji coba lapangan; uji coba lapangan dilakukan pada siswa kelas V SD Negeri Muneng.

\section{HASIL PENELITIAN DAN PEMBAHASAN}

Data validasi LKS yang diperoleh dari lembar validasi LKS berbasis pendekatan Realistic Mathematics Education dikategorikan baik. Rata-rata hasil validasi menunjukkan bahwa LKS berbasis Realistic Mathematics Education (RME) yang dikembangkan oleh peneliti termasuk dalam kriteria cukup valid dengan presentase $82,689 \%$. Sehingga LKS tersebut dapat digunakan untuk uji coba terbatas dan uji coba lapangan dengan sedikit perbaikan.

Data analisis kepraktisan LKS berbasis Realistic Mathematics Education yang diperoleh dari hasil pengisian angket sebagai respon dari siswa setelah menggunakan LKS. Angket respon siswa menggunakan skala Likert dengan metode checklist. Skala Likert digunakan untuk mengukur sikap, persepsi, dan pendapat seseorang (Sugiyono, 2015: 165). Lembar Kerja Siswa (LKS) berbasis Realistic Mathematics Education (RME) dapat memenuhi kriteria kepraktisan media jika presentase lebih dari $70 \%$. Jika kurang dari $70 \%$ maka peneliti harus melakukan perbaikan sesuai saran siswa (Trianto, 2009: 234).

1) Hasil Pengisian Angket Respon Siswa pada Uji Coba Terbatas.

Hasil pengisian angket respon siswa oleh 6 siswa kelas V SD Negeri Pulerejo 3, menunjukkan presentase respon siswa pada uji coba terbatas yaitu $88,75 \%$. Sehingga dapat disimpulkan bahwa LKS berbasis Realistic Mathematics Education (RME) pada uji coba terbatas memenuhi kriteria kepraktisan karena presentase positif responden lebih dari $70 \%$. 
2) Hasil Pengisian Angket Respon Siswa pada Uji Lapangan

Hasil pengisian angket respon siswa oleh 25 siswa kelas V SD Negeri Muneng, menunjukkan presentase respon siswa pada uji coba lapangan yaitu $80,7 \%$. Sehingga dapat disimpulkan bahwa LKS berbasis Realistic Mathematics Education (RME) pada uji coba lapangan memenuhi kriteria kepraktisan karena presentase positif responden lebih dari $70 \%$

Data keefektifan LKS berbasis Realistic Mathematics Education (RME) ditentukan dari nilai ketuntasan siswa setelah mengerjakan tes hasil belajar. Setiap siswa dinyatakan tuntas apabila presentase ketuntasan individu $\geq 65 \%$ dari skor maksimal, sedangkan ketuntasan klasikal diperoleh dengan menghitung rata-rata ketuntasan individu (Trianto, 2009: 241). Ketuntasan klasikal tercapai jika $\geq 85 \%$ siswa tuntas secara individu. Rata-rata hasil validasi oleh validator menunjukkan bahwa soal tes hasil belajar termasuk dalam kriteria valid dengan presentase 88,125\%. Sehingga soal tes hasil belajar dapat digunakan untuk uji coba terbatas dan uji coba lapangan dengan sedikit revisi.

1) Hasil Keefektifan pada Uji Coba Terbatas

Keefektifan LKS berbasis Realistic Mathematics Education (RME) ditentukan dari nilai ketuntasan siswa setelah mengerjakan tes hasil belajar. Tes hasil belajar dikerjakan siswa setelah pembelajaran menggunakan LKS berbasis Realistic Mathematics Education (RME). Berdasarkan hasil ketuntasan belajar dapat disimpulkan bahwa LKS berbasis Realistic Mathematics Education (RME) telah memenuhi ketuntasan klasikal dengan ketercapaian ketuntasan $89,33 \%$ dan memenuhi kriteria ketuntasan minimal (KKM) $\geq 75 \%$. Sehingga LKS berbasis Realistic Mathematics Education (RME) siap digunakan dalam uji coba lapangan.

2) Hasil Keefektifan pada Uji Lapangan

Hasil analisis keefektifan dalam uji coba lapangan diperoleh dari hasil ketuntasan belajar siswa dalam menjawab tes hasil belajar. Tes hasil belajar dikerjakan setelah siswa mempelajari LKS berbasis Realistic Mathematics Education (RME). Berikut adalah hasil ketuntasan belajar siswa pada uji coba lapangan.

Berdasarkan hasil ketuntasan belajar dapat disimpulkan bahwa LKS berbasis Realistic Mathematics Education (RME) telah memenuhi ketuntasan klasikal dengan ketercapaian ketuntasan $86 \%$ dan memenuhi kriteria ketuntasan minimal (KKM) $\geq 75 \%$. Sehingga LKS berbasis Realistic Mathematics Education (RME) dinyatakan efektif untuk digunakan dalam pembelajaran.

Berdasarkan hasil tes kemampuan matematis siswa menunjukkan bahwa rata-rata hasil tes belajar siswa adalah sebesar 87,5 sedangkan rata-rata hasil ulangan tengah semester adalah sebesar 74,65 sehingga dapat disimpulkan bahwa LKS berbasis Realistic Mathematics Education (RME) dapat meningkatkan kemampuan matematis siswa.

Berdasarkan pemaparan hasil penelitian di atas, maka diperoleh bahwa pembelajaran dengan LKS berbasis Realistic Mathematics Education (RME) dapat meningkatkan kemampuan matematis siswa. Hal ini sesuai dengan pendapat Taufiq dan Fahrul Basir (2017) yang menyatakan bahwa "proses pembelajaran seperti ini menekankan keterlibatan sisiwa untuk aktif berinteraksi sehingga dapat 
mengkonstruksi pengetahuannya sendiri”. Dengan demikian dapat disimpulkan bahwa LKS berbasis Realistic Mathematics Education (RME) dinyatakan layak digunakan karena telah memenuhi kriteria valid, praktis, dan efektif serta mampu meningkatkan kemampuan matematis siswa.

\section{KESIMPULAN DAN SARAN}

Berdasarkan hasil penelitian dan pembahasan terhadap Lembar Kerja Siswa (LKS) berbasis Realistic Mathematics Education (RME) yang dikembangkan dapat disimpulkan bahwa:

1. Hasil validasi Lembar Kerja Siswa (LKS) berbasis Realistic Mathematics Education (RME) adalah 82,689\%. Sehingga Lembar Kerja Siswa (LKS) tersebut valid dan dapat digunakan sebagai bahan ajar kelas V Sekolah Dasar pada materi Bangun Ruang.

2. Hasil kepraktisaan Lembar Kerja Siswa (LKS) berbasis Realistic Mathematics Education (RME) dilihat dari angket respon siswa dari uji terbatas adalah $88,75 \%$ dan uji lapangan adalah 80,7\%. Sehingga Lembar Kerja Siswa (LKS) tersebut praktis untuk digunakan sebagai bahan ajar kelas V Sekolah Dasar pada materi Bangun Ruang.

3. Hasil keefektifan Lembar Kerja Siswa (LKS) berbasis Realistic Mathematics Education (RME) dilihat dari tes hasil belajar siswa pada uji terbatas adalah $89,33 \%$ dan uji lapangan adalah $86 \%$. Sehingga Lembar Kerja Siswa (LKS) tersebut efektif untuk digunakan sebagai bahan ajar kelas V Sekolah Dasar pada materi Bangun Ruang.

4. Hasil tes kemampuan matematis menunjukkan bahwa rata-rata hasil tes adalah sebesar 87,5 sehingga dapat disimpulkan bahwa kemampuan matematis siswa meningkat.

\section{DAFTAR PUSTAKA}

Fadilah, A. 2011. Pengembangan Media Game untuk Meningkatkan Hasil Belajar Matematika pada Pokok Bahasan Mata Uang bagi Siswa Tunagrahita Kelas VII Semester II SMPLB C Siswa udhi Surabaya. Skripsi tidak diterbitkan. Surabaya: Program Studi Pendidikan Matematika. (http://digilib.uinsby.ac.id/9358, diunduh 7 Mei 2017)

Fitri, R., Helma, \& Syarifuddin, H. 2014. Penerapan Strategi The Firing Line pada Pembelajaran Matematika Siswa Kelas XI IPS SMA Negeri 1 Batipuh. Vol 3 No. 1

(http://ejournal.unp.ac.id/students /index.php/pmat/article/view/121 4/906, diunduh 7 Mei 2017).

Mulyatiningsih, E. 2013. Metode Penelitian Terapan Bidang Pendidikan. Bandung: Alfabeta.

Prastowo, A. 2015. Panduan Kreatif Membuat Bahan Ajar Inovatif Menciptakan Metode Pembelajaran yang Menarik dan Menyenangkan. Jogjakarta: DIVA Press.

Sugiyono. 2015. Metode Penelitian \& Pengembangan Research and Development. Bandung: Alfabeta.

Taufiq dan Fahrul Basir. 2017. Pengembangan Lembar Kerja Siswa Untuk Meningkatkan Kemampuan Berpikir Kritis Siswa Pada Materi Bangun Ruang Sisi Datar. Prosiding Seminar Nasional Volume 02, Nomor 1 . Http://www.journal.uncp.ac.id/i ndex.php/proceding/issue/view/ 90 
ISSN 2089-8703 (Print) Vol. 7, No. 1 (2018)

ISSN 2442-5419 (Online)

Trianto. 2009. Mendesain Model Pembelajaran Inovatif Progresif Konsep, Landasan dan Implementasinya pada Kurikulum Tingkat Satuan Pendidikan (KTSP). Jakarta: Kencana Prenada Media Group.

Undang-undang Republik Indonesia Nomor 20 Tahun 2003. Tentang Sistem Pendidikan Nasional. (http://pendis.kemenag.go.id/pai /file/dokumen/SisdiknasUUNo. 20Tahun2003.pdf, diunduh 7 Mei 2017)

Wijaya, A. 2012. Pendidikan Matematika Realistik Suatu Alternatif Pendekatan Pembelajaran Matematika. Yogyakarta: Graha Ilmu. 